Gi respons på artikler gjennom artiklenes kommentarfelt på tidsskriftet.no.

Innleggene publiseres fortløpende på Tidsskriftets nettside og et utvalg

av innleggene publiseres også i papirutgaven i spalten «Brev til redaktøren».

Redaksjonen forbeholder seg retten til å foreta redaksjonelle endringer.

Forfattere av vitenskapelige artikler har tilsvarsrett, jf. Vancouver-gruppens regler

\section{Re: Familieplanlegging, graviditet og amming ved multippel sklerose}

I Tidsskriftet nr. 20/2016 publiserte Holmøy \& Torkildsen en oversiktsartikkel om behandling av multippel sklerose i svangerskap og ammeperiode (1). Vi er i hovedsak enige i anbefalingene $\mathrm{i}$ artikkelen, med ett unntak: Vi mener at det ikke er nødvendig å pålegge alle kvinner ammepause under attakkbehandling med metylprednisolon.

På grunn av økt risiko for attakker de første månedene etter fødselen (1) kan attakkbehandling bli aktuelt før ammingen er veletablert. Noen kvinner får vansker med å gjenoppta ammingen etter et ammeopphold på 3-5 dager. En slik anbefaling bør derfor være godt faglig begrunnet.

Det er ikke rapportert bivirkninger hos diebarn ved bruk av glukokortikoider hos mor (2). Begrenset dokumentasjon tilsier at metylprednisolon i liten grad går over i morsmelk, selv ved høye doser. I to kasuistikker ble nivået i morsmelk målt hos kvinner som fikk attakkbehandling (ett gram intravenøst i tre dager) $(2,3)$. Beregnet barnedose for et fullammet barn var maksimalt $0,21 \mathrm{mg} /$ $\mathrm{kg} /$ dag. Dette er betydelig lavere enn terapeutisk barnedose ved for eksempel akutte astmaanfall (1-2 mg/ $/ \mathrm{kg} / \mathrm{dag})$, men nær laveste vedlikeholdsdose på $0,25 \mathrm{mg} / \mathrm{kg} / \mathrm{dag}$ (4). Ved lav dose i 3-5 dager må risikoen for bivirkninger anses å være minimal hos et friskt og fullbårent barn.

Nivået av metylprednisolon i morsmelk synker raskt, og har fire timer etter administrasjonen sunket med $60-80 \%(2,3)$. I en kasuistikk var metylprednisolon ikke påvisbart i morsmelken 12 timer etter infusjonen (2). Ammeopphold på 4-8 timer reduserer barnets eksponering betraktelig. Vi anbefaler dette dersom barnet er prematurt eller sykt. Et slik kortvarig ammeopphold kan også vurderes i andre tilfeller hvis dette er praktisk mulig. Det er etter vår vurdering ingen god faglig begrunnelse for å anbefale ammepause utover 4-8 timer.

Helsedirektoratet har nylig sendt oppdatert versjon av Nasjonal faglig retningslinje for behandling av multippel sklerose ut på høring. Undertegnede ble bedt om å oppdatere kapitlet om graviditet og amming, og vi har foreslått mange forbedringer. Vi er fornøyde med at forfatterne $\mathrm{i}$ arbeidet med artikkelen i Tidsskriftet har tatt hensyn til våre faglige innvendinger. Vi håper at tilsvarende kapittel i veilederen fra Nasjonal kompetansetjeneste for multippel sklerose også oppdateres (5), slik at informasjon på området samsvarer. Dette er nå ikke tilfellet.

\section{Solveig T. Holmsen \\ soholm@ous-hf.no \\ Gro C. Havnen \\ Elisabet Nordmo \\ Hedvig Nordeng \\ Olav Spigset}

Solveig T. Holmsen (f. 1970) er lege, medisinsk rådgiver ved Nasjonal kompetansetjeneste for amming, Oslo Universitetssykehus. Ingen oppgitte interessekonflikter.

Gro C. Havnen (f. 1973) er rådgiver ved RELIS.

Ingen oppgitte interessekonflikter.

Elisabet Nordmo (f. 1972) er seniorrådgiver ved RELIS

Ingen oppgitte interessekonflikter.
Hedvig Nordeng (f. 1972) er professor ved Farmasøytisk institutt, Universitetet i Oslo.

Ingen oppgitte interessekonflikter.

Olav Spigset (f. 1963) er professor ved Avdeling for klinisk farmakologi, St. Olavs Hospital.

Ingen oppgitte interessekonflikter.

Litteratur

1. Holmøy T, Torkildsen $\emptyset$. Familieplanlegging, graviditet og amming ved multippel sklerose. Tidsskr Nor Legeforen 2016: 136: 1726-9.

2. Cooper SD, Felkins K, Baker TE et al. Transfer of methylprednisolone into breast milk in a mother with multiple sclerosis. J Hum Lact 2015; 31: 237-9.

3. National Library of Medicine (USA). Drugs and Lactation database (LactMed). Methylprednisolone. https://toxnet.nlm.nih.gov/lactmed (11.10. 2016).

4. Lexicomp in UpToDate. Methylprednisolone: Pediatric drug information. www.helsebiblioteket.no/ (18.11.2016)

5. Nasjonal kompetansetjeneste for multippel sklerose. Norsk MS-veileder. https://helse-bergen.no/seksjon/MS_veileder/Documents/Kapittel\%203\%20 Forebyggende $\% 20$ behandling/3.2\% 20 Forebyggelde $\% 20$ behandling $\% 20$ ved $\% 20$ graviditet $\% 20$ og $\% 20$ amming.pdf (8.12.2016).

\section{Re: Barn i sårbare livssituasjoner trenger barnevernet}

Takk til M. Hafting \& M. Røynesdal for nyttige synspunkter (1) på vår artikkel (2) i Tidsskriftet. Vi er enige i at «å sikre barn utviklingsfremmende oppvekstsvilkår er en sentral verdi». Vi vil fortsatt fremholde at for å få dette til er det nødvendig å realisere den internasjonale barne- og menneskerettslige forståelse av barns rett både til familieliv og til privatliv. Vi er av den oppfatning at familien er en grunnleggende byggestein i ethvert samfunns sosiale organisering. Retten til familieliv kan ikke erstattes av profesjonelles antakelser om at oppvekstvillkårene er mer utviklingsfremmende i en forsterfamilie. Det finnes det lite forskningsmessig belegg for. Metodene for å diagnostisere mangler i utviklingsfremmende kompetanse hos foreldre er også høyst usikre. Derfor mener vi det er grunn til å advare mot en utvikling der retten til kontakt med egen biologiske familie tillegges mindre vekt, slik det er vist i holdningsundersøkelser i barnevernet (3).

Foreldrefiendtlighet er selvsagt ikke noe isolert amerikansk fenomen. Vi er klar over at der er viktige internasjonale forskjeller i barnevernets rom for skjønnsutøvelse, adopsjonslovgivningen og de formelle krav til saksbehandling. Foreldrefiendtlighet har imidlertid intet med dette å gjøre. Barn skades, uavhengig av nasjonalitet og bosted, ved at den ene biologiske forelder eller fosterforeldre eller terapeuter misbruker barns tillit til å skape fiendebilder av den eller de foreldre som barnet er avskåret fra å møte. Vi vil henvise til et nettsted som gjengir den internasjonale litteraturen som dokumenterer dette (4).

Hafting \& Røynesdal viser til rapporten «Minst hjelp til dem som trenger det mest» fra Nordlandsforskning for å belegge at tilliten er langt større blant brukere av barnevernstjenesten enn blant folk flest (5). Det er den, men i rapporten skriver forskerne at tilliten er stor blant dem som har små og forbigående behov for barnevernstjenester. Brukere som har komplekse og kroniske utfordringer får i liten grad den hjelpen de trenger, og her er tilliten og tilfredsheten liten. Rapporten fra Nordlandsforskning peker på noen utfordringer som nettopp viser at barnevernstjenesten har behov for reformer som gjør ressursbruken mer målrettet og kostnadseffektiv. 
Vi vil peke på noen reformforslag som kan være aktuelle. For det første bør tilsyn etter bekymringsmeldinger i større grad overlates til helsestasjon og skolehelsetjeneste. For det andre bør barnevernet i større grad vektlegge utviklings- og kompetansefremmende tiltak framfor erstattende støttetiltak fordi de er bedre forskningsmessig belagt. For det tredje bør barnevernstjenesten deles i en tjeneste som driver med utviklings- og kompetansefremmende tiltak og en del som tar hånd om tvangstiltak. Eventuelt bør sistnevnte overlates til politiet

Vi er enig i at barnevernstjenesten trenger tillit for å utføre sitt samfunnsoppdrag. Rapporten fra Nordlandsforskning understreker også at vi må ha et kritisk lys på barnevernet (5). Tillit uten kritikk kan lett utvikle seg til servilitet. Det er ingen tjent med.

\section{Eivind Meland}

eivind.meland@uib.no

Lena Hellblom Sjögren

Eivind Meland (f. 1950) er fastlege i Bergen og professor i allmenn- og samfunnsmedisin ved Universitetet i Bergen. Han har hatt en langvarig interesse for fagetiske spørsmål og har ytret seg om slike likke minst i Tidsskriftets spalter) i nær 30 år.

Interessekonflikter: Han har vært medunderskriver på en petisjon til familie- og likestillingsministeren med det formål å bedre rettssikkerheten i barnevernsrettslige spørsmål og sikre god kvalitet i barnevernstjenesten. Han deltar også i et nettforum, kalt Faglig barnevernsforum, med identisk målsetting.

Lena Hellblom Sjögren (f. 1948) er filosofie doktor og psykolog. Hun har vært redaktør for KRitisk UTbildningstidskrift (KRUT), forfatter og foreleser. Interessekonflikter: Hun har via sitt selskap Testimonia og 3V-förlaget arbeidet med utredningsoppdrag og gitt juridisk hjelp til foreldre i barnevernssaker i Sverige og i andre land, deriblant Norge.

\section{Litteratur}

1. Hafting M, Røynesdal M. Barn i sårbare livssituasjoner trenger barnevernet. Tidsskr Nor Legeforen 2016; 136: 1877.

2. Meland E, Sjögren LH. Når barn skades med de beste hensikter. Tidsskr Nor Legeforen 2016: 136: 1334-5.

3. Backe-Hansen E, Havik T, Backer Grønningsæter A. Fosterhjem for barns behov. NOVA-rapport 16/13. Oslo: NOVA, 2016

4. Parental Alienation Database [database on the Internet]. Vanderbilt University Medical Center. 2016 [cited 7.12.2016]. Available from: http://mc.vanderbilt.edu/ pasg/. (8.12.2016)
5. Clifford G, Fauske H, Lichtwarck W et al. Minst hjelp til dem som trenger det mest? Sluttrapport fra forsknings- og utviklingsprosjektet «Det nye barnevernet». NF-rapport 6/2015. Bodø: Nordlandsforskning, 2015: 67-9.

\section{Medikamentell behandling av eldre mennesker med funksjonssvikt}

Med min bakgrunn som allmennlege i 50 år og 25 år som sykehjemslege ønsker jeg å reise en problemstilling. Gamle mennesker med sammensatte lidelser står ofte på flere medikamenter og må ikke sjelden innta en seks til åtte forskjellige tabletter i døgnet. Medikamentene skal gjerne inntas til forskjellige tidspunkt om dagen.

Ofte bor de eldre hjemme, gjerne alene, og har bevart sin mentale funksjon, men har gjerne svekket syn og dårlig finmotorikk i hånd og fingre. Langt fra alle har løsning med medikamentdosett.

Legemiddelverket pålegger for blåresepter bytte til generisk preparat når dette er billigere. Men kopipreparatene kan ha en annen størrelse, form og farge enn originalpreparatet. Det kan føre til forveksling og feildosering, med de alvorlige medisinske konsekvenser dette medfører. Et annet problem er de nyere blisterpakningene som er vanskelig å håndtere for gamle med nedsatt førlighet $i$ hånd og fingre. Tablettene vil ofte ikke ut av pakningene og plutselig spretter de på gulvet fra bordet.

Mitt forslag er at kopipreparatet skal ha samme størrelse, form og farge som originalpreparatet for å godkjennes, og at tablettene skal leveres i boks med skrulokk. Dette møter nok motstand fra legemiddelprodusenter.

Det er meningsløst at mange preparater fra kopiprodusenter som Nav betaler på blåresept, håndteres og doseres feilaktig av den gamle pasient, med store helsemessige og kanskje også livsfarlige konsekvenser.

Per Steinar Steinsvoll

ststeins@online.no

Per Steinar Steinsvoll (f. 1934) har tidligere jobbet 50 år som allmennlege og 25 år som sykehjemslege i Sel kommune.

Ingen oppgitte interessekonflikter. 